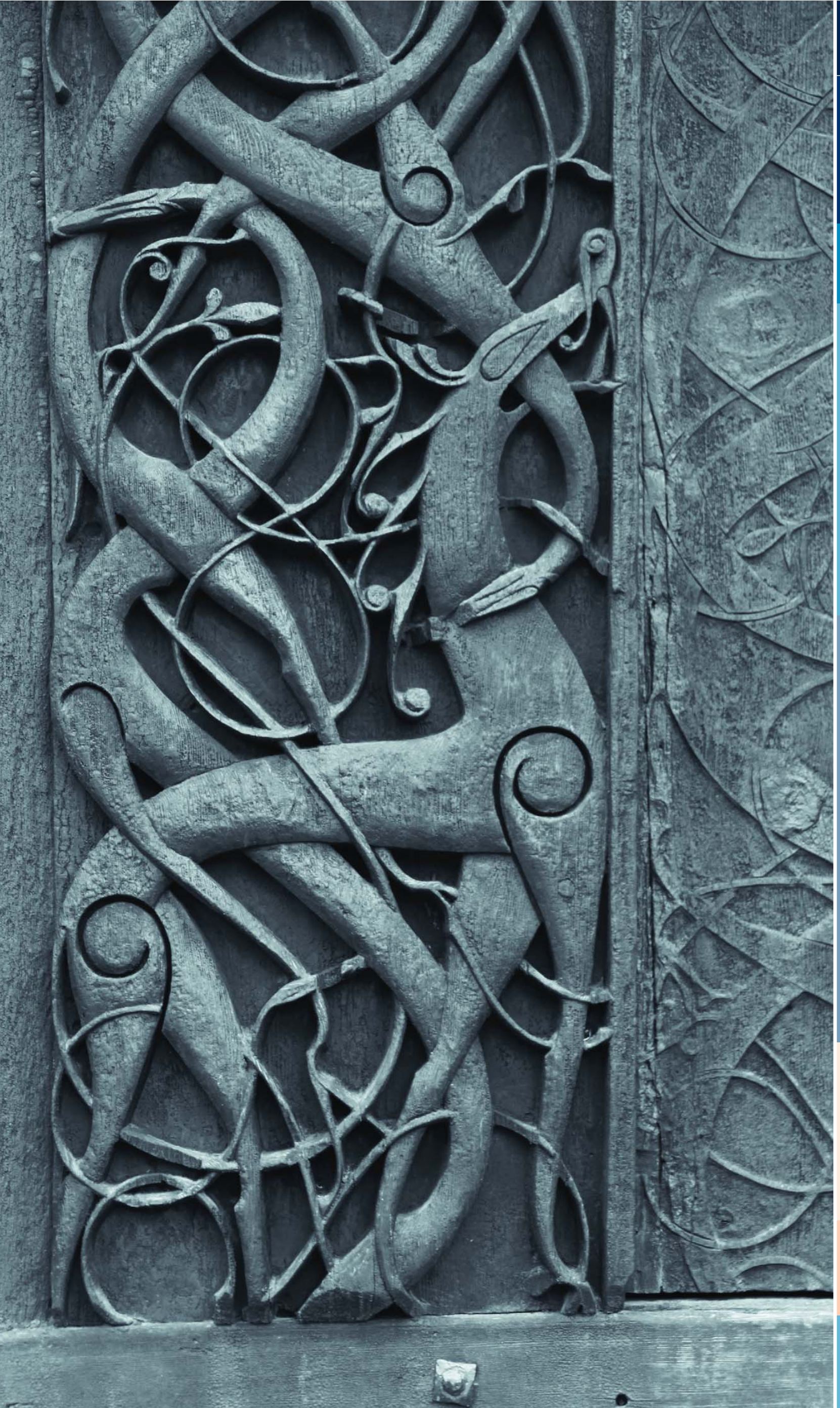




\section{Между язычеством}

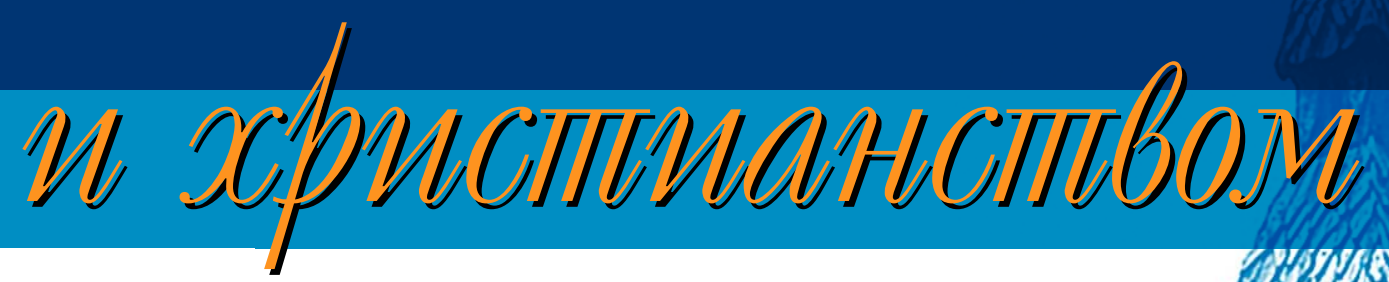

Древние беспощадные боги помогали викингам сохранять воинственный дух и решительность в сражениях, требуя в ответ достойных жертвоприношений. По свидетельству немецкого автора XI века Адама Брементского в Упсале, главном культовом центре языческой Скандинавии, каждые девять лет жрецы закалывали девять видов живых существ - в том числе и людей. Чаще всего в жертву богам предназначали врагов, захваченных в плен, но известны случаи, когда жертвенный ритуал совершался даже над сыном вождя. Норвежский король Хакон в конце Х века предал смерти своего сына Эрлинга, дав этот обет богам за победу в войне с нежелающими покориться ему землями..

4 Горельеф из церкви в Урнесе, изображающий «хватающего зверя». Внешне резьба напоминает рисунок на древних рунических камнях, на которых запечатлена битва змея Ёрмунганда и перевоплощенного бога Тора.

Ирландский епископский посох найден в поселении викингов Хельгё, в Швеции. X-XI в.

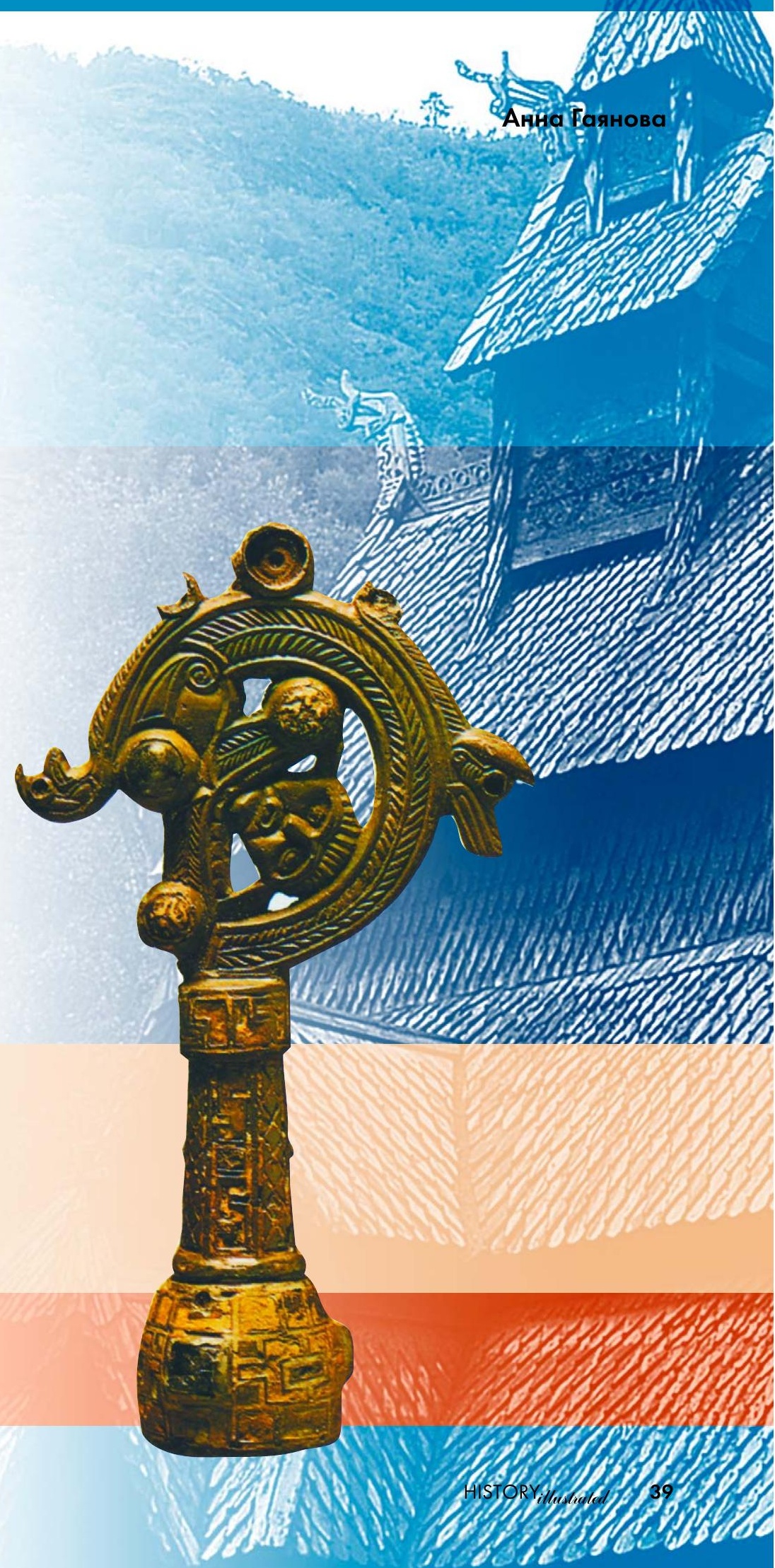




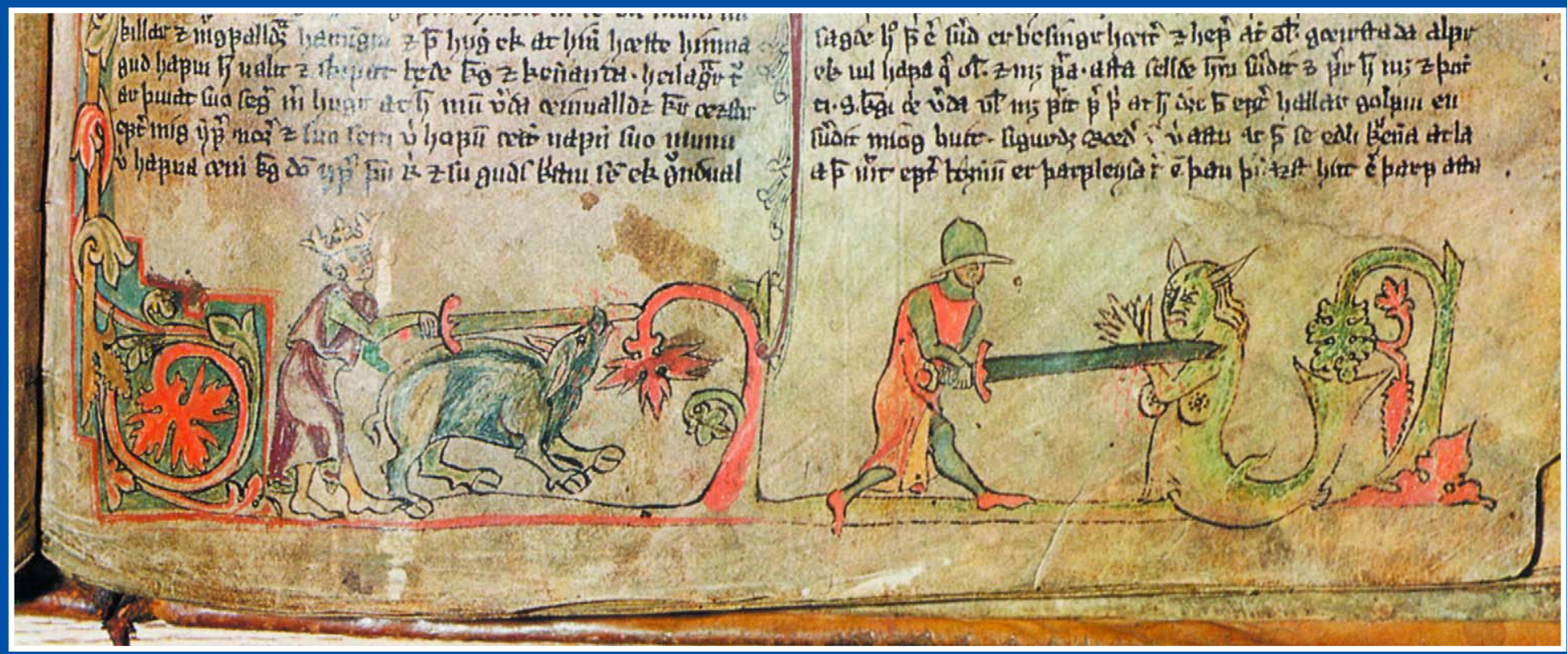

Фрагмент страницы «Саги об Олафе Трюггвасоне», написанной исландским историком и поэтом Снорри Стурлусон в XIII в.

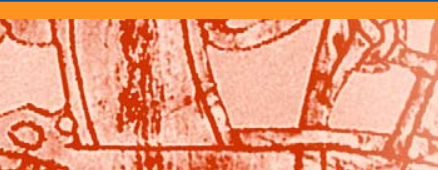

Древняя деревянная церковь в Урнесе, построенная в 1130 году, $\Rightarrow$ известна необычными резными горельефами, пронизанными причудливыми образами древнего язычества.

Христианство постепенно вытесняло язычество, но древние верования прочно удерживались в сознании викингов, и религиозные верования скандинавских народов долго ещё балансировали на грани язычества и христианства. Особенно ярко это смешение проявилось в архитектуре деревянных церквей, украшавшихся резными головами драконов, подобных тем, которые венчали штевни кораблей викингов.

Однако уже с VIII века в Скандинавию все чаще отправлялись христианские миссионеры из Европы, во многом стараниями европейских монархов, которые стремились умерить воинственный дух беспокойных соседей.

Стремясь возвысить свою власть, некоторые скандинавские правители принимали крещение сами и заставляли перейти в новую веру своих подданных. В 826 году датский король Харальд Клак стал христианином вместе со всей своей семьей. Его примеру последовали другие вожди, заинтересованные в поддержке европейских монархов. Король Дании Харальд Синезубый - в 965 году, на рубеже X-XI веков король Норвегии Олаф
Трюггвасон и король Швеции Олаф Шетконунг крестили своих подданных, стремясь укрепить свою власть и объединить свои земли.

Зачастую распространение христианства встречало упорное сопротивление и имело насильственный характер. Король Олаф Трюггвасон, к примеру, врывался с дружиной в святилища, разбивал изображения древних богов, и уничтожал всех, кто отказывался принимать новую веру. Одно из норвежских преданий повествует об ужасной пытке, которой был подвергнут вождь Раут за отказ креститься. Полую трубку с помещённой в ней живой гадюкой насильно протиснули ему в горло, и Раут 


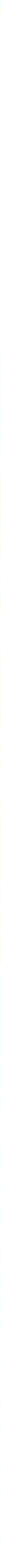

